\title{
Building the Nation
}

\author{
Geoffrey A. Wright
}

John A. Hall, Ove Korsgaard, and Ove K. Pedersen (ed.), Building the Nation: N.F.S. Grundtvig and Danish National Identity, Montreal, McGill-Queen's University Press, 2015, Paperback, 453 pp., $\$ 34.95$.

Building the Nation is an impressive volume that delves into the multifaceted legacy of Nikolai Frederik Severin Grundtvig, a giant in Danish history and literature and "the single person most responsible for the national culture and political thinking that came to characterize the Denmark of the late nineteenth and twentieth centuries" (110). The editors, John Hall, Ove Korsgaard, and Ove Pedersen, set out to accomplish a twofold purpose: first, to comprehend the development of Danish nationhood as a project that occurred largely under the guidance of N. F. S. Grundtvig (4) and, second, to make a case for understanding Grundtvig himself as a political figure (413). In doing so, the editors hope to fill a gap in our popular reception of Grundtvig as a minister, poet, philosopher, and educational reformer (413). Without a doubt, Hall and company achieve these goals, insofar as they make a convincing case for Grundtvig's intervention in political debates of his time and for his contribution to a uniquely Danish version of enlightened, liberal government.

A collection this large - it contains twenty-one essays bookended by the editors' introduction and conclusion - could easily collapse under its own weight. However, the editors' keen sense of structure holds the volume together. It is organized into five segments: the first lays a broad theoretical foundation for the concepts of nationhood and nation building, and the second explores the historical context for the emergence of the Danish nation; with this groundwork in place, the third segment begins 
the real work of the collection by examining Grundtvig as the political champion of the Danish people, despite his ambivalence toward democracy; the fourth takes an eclectic approach in comparing Grundtvig to nineteenth-century contemporaries as diverse as Émile Durkheim, Ralph Waldo Emerson, and Søren Kierkegaard; finally, the fifth segment explores the afterlife of Grundtvig's philosophy as it lives on in the varied political, educational, scientific, and even athletic movements collected under the banner of Grundtvigianism. With few exceptions, Building the Nation maintains admirable consistency in terms of quality across its almost two-dozen essays. Each is thoroughly researched and boasts a substantial bibliography. In light of this volume's sheer size, it is impractical to comment on all twenty-one of the essays. So, my approach is to assess the essays in each section collectively, commenting on how each section contributes to the book's overarching mission.

Part One, "Theoretical Groundwork," and Part Two, "Enabling Conditions," are preliminary to the central work of Building the Nation, which is to analyze the nature and impact of Grundtvig's political philosophy. While these two sections might not be necessary for historians and political scientists, they are useful for non-specialists in defining terms and in outlining key historical events surrounding the emergence of Denmark as a nation. In Part One, Francis Fukuyama sketches a four-stage process necessary to nation building, whether that nation is Denmark or any other: "(1) the defining of political borders to fit populations, (2) the moving or physical elimination of populations to fit existing borders, (3) the cultural assimilation of subpopulations into the dominant culture, and (4) the modification of the concept of national identity to fit what is politically feasible" (33). Denmark's history follows this pattern. In Part Two, Uffe Østergaard charts the events in Denmark's history that pruned the territories of Norway, Schleswig, and Holstein from Denmark during the early to mid-nineteenth century, consolidating Denmark into an ethnically homogeneous population ready to be molded into a singular national identity.

Part Three, "Grundtvig and the People," and Part Four, "Comparisons," are the most pivotal sections of Building the Nation. They perform the bulk of the work of analyzing the complexities of Grundtvig's views on Enlightenment liberalism, rationalism, and individualism, views that helped shape a uniquely Danish set of socio-political values and practices. 


\section{BuIlding THE NATION}

Ironically, democracy in Denmark came about in part through the work of Grundtvig, who was, in a sense, anti-democratic: he disapproved of the British parliamentary system and favored an enlightened monarchy. Tine Damsholt explains that Grundtvig "only acknowledges the king when the latter regards himself as the interpreter of the voice of the people, and he only acknowledges the population as a people once they acknowledge their responsibility towards the common good" (158). In this way, Grundtvig envisions a social contract akin to that of John Locke, but one that binds together the people and their king rather than a people and their elected officials (165).

The question of how to balance the nascent values of freedom and individual rights with the need for order and stability becomes a theme in sections three and four. In Part Four, Ole Vind contrasts Grundtvigian and British versions of liberalism, demonstrating that, while British liberalism grew to favor the rational individual over the collective, Grundtvig always believed that the purpose of freedom was to enrich the larger spiritual good of the Danish people as a whole. The tension between individuality and community is apparent in the comparisons between Grundtvig and Emerson and Kierkegaard. Troels Nørager sees Grundtvig and Emerson as parallel figures who establish a "civil religion" (290) in their respective countries. Though Grundtvig would disapprove of the "mystical tendency" in Emerson's writings (295), both thinkers endorse a positive view of human nature "by virtue of being created in the image of God" (295). For Grundtvig, this shared, divinely designed nature enables individuals to bond together in community. Matias Møl Dalsgaard provides a contrasting view. He observes that whereas Grundtvig "views Christianity as a collective practice carried out in culture and congregation, [. . . Kierkegaard views any sort of collectivity (in the name of Christianity or not) with great suspicion" (303). Through these debates over the relationship between the individual and society, Grundtvig shapes not only Danish politics but also Danish faith.

The final section, Part Five, turns away from Grundtvig the person to explore the surprisingly varied movements in which his values find expression. The creation of People's High Schools all across Denmark is one of the most significant and lasting aspects of Grundtvig's legacy. Ove Korsgaard observes that the schools educated Danish adolescents in order "to integrate them into a national and democratic community and [. . .] to 
give them training in agriculture and housekeeping" (320). For Grundtvig, having an educated or enlightened citizenry is essential to the fulfillment of the common good. Grundtvig's empowerment of the people had other positive yet unintended consequences. Henning Eichberg writes on Danish athletics and "movement culture" (346), which became a practical expression of a comprehensive view of life and health. Though Grundtvig was skeptical of Enlightenment rationalism, his followers, according to Hans Henrik Hjermitslev, "popularized scientific and technological knowledge" (363), which led to a successful agricultural industry dominated by a cooperative system (373).

One criticism I have to offer regarding this book might not be entirely fair: it reads as a celebration of Grundtvig almost as much as it does a critical study of his pervasive influence on Danish society. Granted, it would be difficult to criticize "the Moses of the Danish nation" (4); however, a scholarly volume that achieves such broad scope should, in my estimation, have room to view even the problematic effects that Grundtvig himself or the various movements collected under the banner of Grundtvigianism have had on Danish society. Yet, of the twenty-one essays in this volume, I find only one that is even partially critical of the Danish hero: it is a fascinating study of "The Economic Consequences of the Size of Nations" by John L. Campbell and John A. Hall. The essay concludes that "the Grundtvigian lecacy is somewhat troubled," particularly on the topic of immigration (408). Campbell and Hall explain that, while Denmark's cultural homogeneity - which was cultivated by Grundtvig - was a strength amid the nationalistic conflicts of the twentieth century, it has become a problem in an increasingly globalized world. As a result, they ask a potentially controversial question: "Is it the case that Denmark will be able to assimilate immigrants - that is, to become a civic nation - given that, in light of its homogeneous background, multiculturalism is not really an option?" (408). This essay spoke to a question I - as a non-Danish reader - had in my mind, a question about how easy it might be for the celebration of any nation's "essential" cultural heritage to turn xenophobic.

Yet, questions such as these are raised sparingly in Building the Nation. In this light, it is revealing that Ove Pedersen admits that he was surprised by "the difficulty of achieving an impartial approach to Grundtvig as a person, writer, and legend" (413). He goes on to relate that Grundtvig's "position in Danish historiography has proved to be so substantial that 
we have had our work cut out to establish a methodical distance between ourselves and Grundtvig as our subject" (413). The editor's confession also acts as a defense of sorts. Pedersen concludes, "This book's contribution points to something typical: namely, that there is no generally acknowledged approach to studying one's own national identity or how, impartially, to methodologically implement such an approach" (414). Pedersen resigns himself to the power of Grundtvig's reputation and argues that this volume should be received as the embodiment of the "methodological and theoretical tensions" built into the act of inquiring into the nature of one's own nation's political history (414).

Despite this criticism, Building the Nation deserves a wide readership. It will surely prove itself essential to Grundtvig specialists on both sides of the Atlantic. Insofar as the book covers a wide range of topics related to Grundtvig's contributions to Danish politics, philosophy, poetry, religious practices, and education, scholars with interests in fields as diverse as Northern European history and literature, Danish political history, Enlightenment liberalism, Sociology, and Reformation theology will be able to mine this collection for useful essays. Far reaching yet focused, this volume sets up Grundtvig as a prism, refracting the light of Danish culture into an array of projects for the spiritual, political, and pedagogical liberation of the Danish people and the affirmation of a collective Danish identity. 